\title{
VEGENERIO (WEGENER) GRANULIOMATOZĖS PASIREIŠKIMAS OFTOLMOLOGINIAIS POKYČIAIS: KLINIKINIS ATVEJIS
}

\author{
Gabija Bagužyte்1, Deimantė Užkuraityte் ${ }^{1}$, Agnẻ Sidaraite் ${ }^{2}$, \\ Loreta Bandziené2 ${ }^{2}$ Daiva Stanislovaitien $\dot{e}^{2}$ \\ ${ }^{1}$ Lietuvos sveikatos mokslu universitetas, Medicinos akademija, Medicinos fakultetas, \\ ${ }^{2}$ Lietuvos sveikatos mokslu universitetas, Akiu ligu klinika
}

Raktažodžiai: Vegenerio granuliomatozè, granuliomatozè su poliangitu, vaskulitas, ANCA, nekrotizuojanti granulioma, sinonazalinè liga, sisteminès ligos akių išraiška.

\begin{abstract}
Santrauka
Granuliomatozè su poliangitu arba Vegenerio granuliomatozė yra reta autoimuninè liga, dažniausiai pasireiškianti kvėpavimo takų bei inkstų pažeidimu. Oftalmologiniais pokyčiais liga prasideda $30-50$ proc. atvejų. Diagnozę patvirtina specifiniai histologiniai pokyčiai granuliomatozinis uždegimas, nustatomas tiriant biopsinę medžiagą iš pažeisto organo arterijos ar perivaskulinès zonos ir teigiamas antineutrofilinių citoplazminių antikūnų tyrimo rezultatas. Granuliomatozès su poliangitu klinikinè baigtis gali būti letali, tačiau laiku atlikta diagnostika ir šiuolaikinès individualizuoto gydymo citotoksiniais bei imunosupresiniais medikamentais galimybès reikšmingai pagerina ligos prognozę. Straipsnyje pristatomas granuliomatozès su poliangitu klinikinis atvejis, kai diagnozè įtarta pasireiškus oftalmologiniams požymiams. Patvirtinus diagnozę, taikytas medikamentinis bei chirurginis gydymas, pasiekta granuliomatozès su poliangitu remisija.
\end{abstract}

\section{Ivadas}

Granuliomatozė su poliangitu (GP), dar žinoma kaip Vegenerio granuliomatozè - reta autoimuninè liga, pasireiškianti nekrotizuojančiu smulkiujų kraujagyslių vaskulitu [1]. Pasaulyje diagnozuojami 5-10 GP atvejų milijonui gyventojų per metus, liga labiau paplitusi tarp baltosios rasès atstovu [2]. Vidutinis sergančiujų amžius 50-60 metų, moterų ir vyrų susirgimų dažnis vienodas [2- 4]. GP dažniausiai pasireiškia viršutinių ar apatinių kvėpavimo takų simptomais kartu su glomerulonefrito požymiais. Rečiau nustatomi akių, ausų, odos bei širdies ir kraujagyslių sistemos pažeidimai [3].

Dèl ribotų gydymo galimybių iki $1970 \mathrm{~m}$. GP buvo laikoma mirtina liga: vos 50 proc. pacientų, gydomų gliuko- kortikoidais, išgyvendavo 5 mėnesius, mirštamumas siekė 80 proc. per vienerius metus [5]. Šiuolaikinès individualizuoto gydymo citotoksiniais bei imunosupresiniais medikamentais galimybès reikšmingai pagerino ligos baigtị [6-7], tačiau problematiška išlieka GP diagnostika, nes tai reta patologija, o ligos eiga gali būti nestandartinè.

GP 30-50 proc. atvejų prasideda nespecifiniais oftalmologiniais pokyčiais [8-9]. Galimas granuliomatozinis junginès, kraujagyslinio dangalo, tinklainės ar akiduobės minkštụjų audinių uždegimas [5]. GP diagnozę patvirtina specifiniai histologiniai pokyčiai - granuliomatozinis uždegimas, stebimas tiriant biopsinę medžiagą iš pažeisto organo arterijos ar perivaskulinès zonos [10] ir teigiamas antineutrofilinių citoplazminių antikūnų (ANCA) tyrimo rezultatas [11].

Straipsnyje pristatomas klinikinis atvejis, kai GP diagnozuota pasireiškus oftalmologiniams ligos požymiams. Pacientui taikytas medikamentinis bei chirurginis gydymas ir pasiekta GP remisija.

Tikslas - pristatyti retos autominuninès kilmès granuliomatozès su poliangitu, diagnozuotos tik pasireiškus oftalmologiniams pažeidimams, klinikinį atvejị.

\section{Klinikinis atvejis}

Stacionare gydomas 56 metų vyras, kuriam buvo atlikta dešiniosios sèklidès pašalinimo operacija dèl neaiškios kilmès sèklidès ir kirkšnies absceso, pasiskundè kairiosios akies skausmu. Gydytojo oftalmologo konsultacijos metu nustatyta nepakitusi dešiniosios akies rega $(\mathrm{V} \mathrm{OD}=1,0)$ ir kairiosios akies regejjimo aštrumo sumažèjimas ( $\mathrm{V} \mathrm{OS}=$ $0,6)$. Objektyviai: kairiosios akies ragenos limbo sritis cirkuliariai suplonejjusi, viršutiniuose kvadrantuose įaugusios kraujagyslès, besiformuojančios baltos drumstys, ragenos centre - paviršiniai taškiniai epitelio defektai, besidažantys fluoresceinu. Kairiosios akies dugne bei dešiniojoje akyje patologinių pokyčių nestebèta. Paskirtas kairiosios akies gydymas plataus veikimo spektro antibiotikų lašais, tepalas nakčiai ir drèkinamieji akių lašai. Rekomenduota reu- 


\section{8}

matologo konsultacija dèl ịtariamo sisteminio susirgimo.

Praejjus dviem savaitėms, pacientas kreipèsi ị oftalmologą dèl akių skausmo ir šviesos baimès. Vargino varvèjimas iš nosies, svetimkūnio jausmas ausyje ir pablogejusi klausa. I reumatologą ar ausų nosies gerklès gydytoją dar nesikreipè. Oftalmologinio tyrimo metu nustatytas progresuojantis abiejų akių regèjimo sutrikimas ( $\mathrm{V} \mathrm{OD}=0,5 ; \mathrm{V}$ $\mathrm{OS}=0,2)$. Dešiniojoje akyje stebèta saiki mišri junginès injekcija, negilus infiltratas ties ragenos kraštu nuo 4 iki 5 val.; kairiojoje - mišri junginès injekcija, dinamikoje platesni ir gilūs ragenos limbo srities suplonèjimai (nuo $10 \mathrm{iki}$ 12 val.). Diagnozuotas abiejų akių marginalinis keratitas, kairiosios akies skleritas (1 pav.). Pacientas nusiųstas ị akių ligų stacionaro skyrių detaliau ištirti ir gydyti.

Atlikus kraujo tyrimus, nustatyta anemija $(\mathrm{Hb} 91 \mathrm{~g} / \mathrm{l})$, saiki leukocitozè $\left(10,9 \times 10^{9} / 1\right)$, trombocitozè $\left(509 \times 10^{9} / 1\right)$, C reaktyviojo baltymo padidejimas $(47,4 \mathrm{mg} / \mathrm{l})$ ir eritrocitu nusėdimo greičio pailgejjimas $(109 \mathrm{~mm} / \mathrm{h})$. Imunologiniuose tyrimuose nustatyti teigiami ANCA antikūnai ir c-ANCA tipo švytëjimas. Galvos kompiuterinès tomografijos tyrime stebèta netolygiai sustorejusi sinusų gleivinè, kairysis kaktinis ir pleištakaulio ančiai bei kairioji vidurinioji ausis buvo užpildyti minkštojo audinio tankio turiniu (2 pav.).

Iškviestas ausų, nosies ir gerklès ligų gydytojas. Konsultacijos metu įtarus navikini procesą, atlikta nosies gleivinès biopsija. Nustatyta židininè nekrozė, vaskulitas, uždegiminiai pakitimai, būdingi granuliomatozei su poliangitu. Pacientas perkeltas ị reumatologijos skyrių, sisteminiam gydymui skirti gliukokortikoidai (metilprednizolonas $16 \mathrm{mg} / \mathrm{d}$ ).

Po dviejų dienų ligonis pakartotinai konsultuotas oftalmologo: akių skausmu ar regos pokyčiais nesiskundė, tačiau kairiojoje akyje nustatyta ragenos limbo srities perforacija ties 10:30 val., žaizda buvo tamponuota rainele (3 pav.). Skubiai atlikta kairiosios akies pasluoksninè keratoplastika ir dengimas amniono membrana. Itvertinus gyvybei ir (ar) organui (akiai) pavojingą pažeidimą, remiantis rekomendacijomis, koreguotas sisteminis gydymas - pradèta biologiné terapija rituksimabu [9]. Esant gerai biologinės terapijos

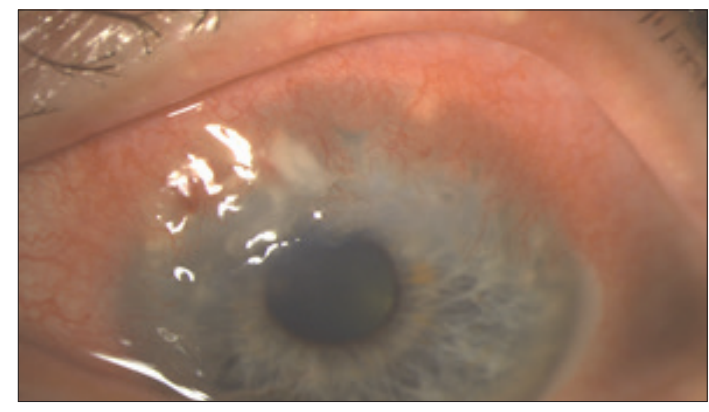

1 pav. Kairiosios akies marginalinis keratitas ir skleritas tolerancijai, pacientas išleistas gydytis ambulatoriškai ir periodiškai atvyksta ị dienos stacionarą biologinès terapijos kursui.

\section{Diskusija}

Granuliomatozė su poliangitu skirstoma ị lokalią (tik kvėpavimo sistemos pokyčiai) ir sisteminę (kvėpavimo takai nepažeisti, tačiau sutrikimai nustatomi inkstuose ir kituose organuose) [12]. M. Ahmed ir kolegos aprašè kelis GP atvejus, kai buvo pažeistos tik akys, o kvėpavimo sistemos ar inkstų ligų požymių nebuvo [13]. Mūsų atveju, pacientas nurodè regos aštrumo pablogéjimą, vèliau - akies skausmą, šviesos baimę. A. Davila-Camargo ir bendraautorių duomenimis, sergant GP akių skausmas nustatomas net 73,3 proc. pacientų [14]. Dèl odeną, junginę ir periferinę rageną maitinančių priekinių ciliarinių arterijų vaskulito, GP gali

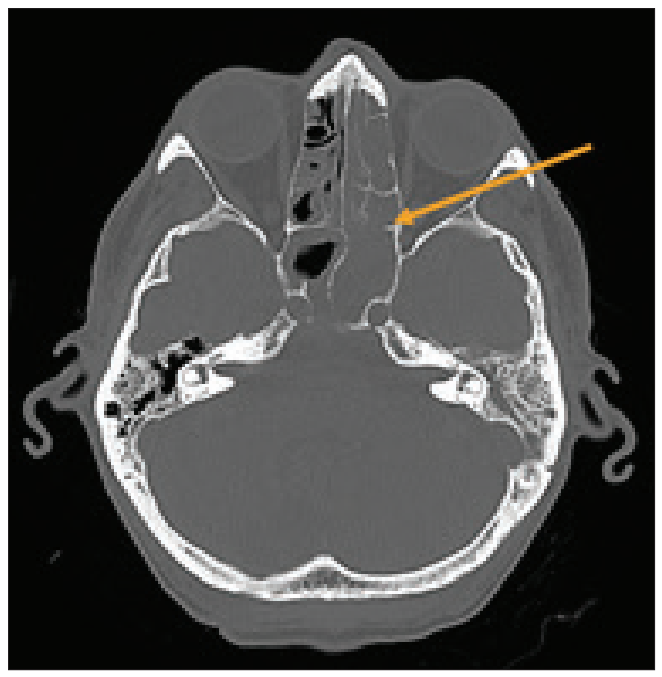

2 pav. Netolygiai sustorejusi sinusų gleivinė, kairysis kaktinis ir pleištakaulio ančiai bei kairioji vidurinioji ausis, užpildyti minkštojo audinio tankio turiniu

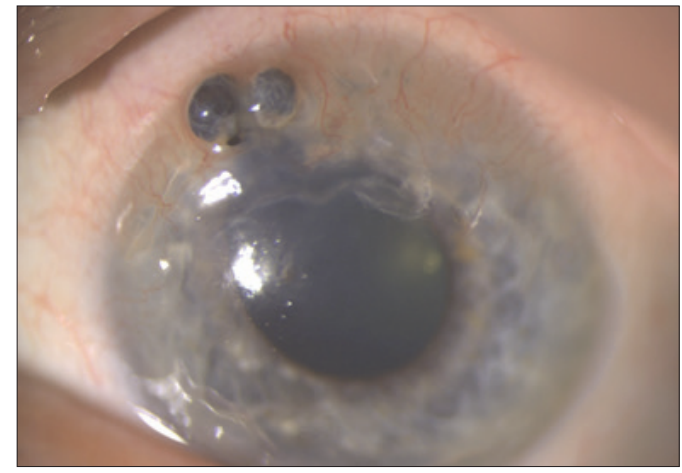

3 pav. Kairiosios akies ragenos perforacija, žaizda tamponuota rainele ties 10:30 val. 
pasireikšti keratitu bei nekrotizuojančiu skleritu, kuriam būdingas odenos suplonèjimas, perforacija $[1,12]$. Mūsų aprašomam pacientui buvo diagnozuotas marginalinis keratitas bei skleritas. Remiantis A. Tarabishy ir kolegų tyrimu, periferinis opinis keratitas, sergant granuliomatoze, susijęs su autoantikūnais prieš citokeratiną-3 ir yra blogesnès ligos eigos prognozinis žymuo [5].

Kitos galimos oftalmologinès GP išraiškos - akiduobès, junginès, tinklainès, gyslainès pažeidimai, uveitas [5]. E. Sfiniadaki ir kitų autorių teigimu, granuliomatozinis akiduobės minkštujų audinių uždegimas, akies judrumo sumažejimas, epifora gali būti nustatomi beveik pusei sergančiųjų [12]. Granuliominėms masėms spaudžiant regos nervą, sukeliama regos nervo atrofija, kuri gali sukelti negrižtamą regos netekimą, todèl nedelsiant būtinas adekvatus gydymas [1]. Konjunktyvitas būdingas apie 20 proc. pacientų [3, 8, 12]. Nors uveitai dažnai siejami su autoimuninemmis ligomis, jų pasireiškimas sergant GP gana retas $[5,8,12]$. Tinklainès ir gyslainès pokyčiai GP metu nèra dažni, bet vaskulitas gali sukelti tinklainès arterijos nepraeinamumą, galimas geltonosios dėmès paburkimas, chorioretinitas, eksudacinè tinklainès atšoka ir tinklainès nekrozė $[8,12]$.

Mūsų aprašomuoju atveju pacientui pasireiškè ir kitų sisteminių GP požymių: rinorēja, sinusitas, klausos sutrikimas. B. Grygiel-Górniak ir kiti autoriai rašo, jog daugiau nei pusei sergančiujų GP nustatomas sinusitas, nosies obstrukcija, rinorejja [3]. Su GP susiję sinusų ir nosies srities pokyčiai gerai matomi KT arba MRT vaizduose. Pradinèse ligos fazėse galimas nespecifinis viršutinės žandikaulio antralinės gleivinès sustorèjimas, vèliau vystosi nosies pertvarą, priekinę akytkaulio sriti apimanti kaulo destrukcija. Progresuojant ligai, audiniai nyksta, o pažeidus nosies tiltelị, susiformuoja tipiška „balno nosis“" [15].

Klausos pažeidimas nustatomas apie 35 proc. pacientų, sergančių GP. Galimos išraiškos: viduriniosios ausies serozinis otitas, klausos praradimas, vertigo, mastoiditas [16]. Dažniausiai klausa sutrikdoma dèl lettinio viduriniosios ausies uždegimo, pažeidus klausomuosius kauliukus, arba dèl vaskulito sukelto neurosensorinio pažeidimo [5].

Mažiau nei 1 proc. pacientų GP gali pažeisti širdies ir kraujagyslių sistemą, centrinę nervų sistemą, paausinę liauką ar urogenitalinę sistemą [17-18]. Aprašomuoju atveju pirminiais laikyti oftalmologiniai požymiai pacientui pasireiškè po dešiniosios sèklidès pašalinimo operacijos. Nenustatyta sèklidès ir kirkšnies absceso etiologija leidžia svarstyti ir apie galimą urogenitalinès sistemos GP. G.Turan su kolegomis aprašè GP atvejị, kai be įprastinių pažeidimų, išskirtinai buvo nustatyti sèklidès pažeidimai. Pacientui skundžiantis sẻklidès skausmu ir blogèjančia būkle, buvo nuspręsta atlikti kairiosios sẻklidès pašalinimo operaciją. Po atlikto histopatologinio pašalintų audinių tyrimo, rasta kraujagyslinių pakitimų, patvirtinusių sèklidžių GP diagnozę [18]. Šis ir mūsų aprašytas atvejis įrodo, jog GP pasireiškimo lokalizacija gali būti ịvairi.

Remiantis Amerikos reumatologijos kolegijos rekomendacijomis, GP diagnozę patvirtina du ar daugiau iš šių kriterijų: šlapimo pakitimai (tyrime mikroskopinè hematurija), krūtinès ląstos pakitimai (vaizdo tyrimuose mazgeliai, fiksuoti infiltratai ar ertmés plaučių audinyje), nosies ir (ar) burnos uždegimas (burnos gleivinės opos, pūlingos ir (ar) kraujingos nosies išskyros) ir granuliomatozinis uždegimas, stebimas tiriant biopsinę medžiagą iš pažeisto organo arterijos ar perivaskulinès zonos [10]. R. DeRemee ir kolegų teigimu, GP diagnozę patvirtina būdingi specifiniai histologiniai pažeisto organo pokyčiai ir teigiamas ANCA tyrimo rezultatas [11]. Sergantiems generalizuota GP forma, c-ANCA randami 80-90 proc. atvejų, o p-ANCA prieš mieloperoksidazę - nuo 10 iki 20 proc. sergančiuju $[3,5,12,19]$. Aprašomuoju atveju taip pat buvo gautas teigiamas paciento ANCA rezultatas su c-ANCA tipo švytèjimu bei specifiniai pokyčiai biopsijos mėginyje iš nosies gleivinès. Nustačius diagnozę, skirtas gydymas gliukokortikoidais. Vèliau, atsižvelgiant ị ligos sunkumą, gydymas koreguotas - papildytas rituksimabo terapija. Remiantis patvirtintomis su ANCA susijusių vaskulitu gydymo rekomendacijomis [20], lengvos eigos GP gydomas gliukokortikoidų deriniu su metotreksatu arba mikofenolato mofetiliu. Esant gyvybei ir (ar) organams pavojingų pažeidimų, skiriamas gliukokortikoidų derinys su ciklofosfamidu arba rituksimabu [2-4]. GP nèra išgydoma liga, tačiau šiuo metu sergančiųjų GP 5 metų išgyvenamumas yra 95 proc., o 10 metu - 80 proc. Gydymas citotoksiniais bei imunosupresiniais medikamentais reikšmingai pagerino GP baigti [6-7].

\section{Išvados}

1. Oftalmologiniai granuliomatozės su poliangitu požymiai nespecifiniai, tačiau, kartu su detalia anamneze, leidžia ịtarti smulkiujų kraujagyslių vaskulitą.

2. Granuliomatozès su poliangitu diagnozę patvirtina specifiniai histologiniai pažeisto organo arterijos ar perivaskulinés zonos pokyčiai ir teigiamas antineutrofilinių citoplazminių antikūnų tyrimo rezultatas.

3. Laiku atlikta diagnostika atveria šiuolaikinès individualizuoto gydymo citotoksiniais bei imunosupresiniais medikamentais galimybes ir reikšmingai pagerina ligos baigti.

\section{Literatūra}

1. Říhová E, Svozílková P, Brichová M, Klímová A, Kuthan P, Diblik P. Ocular Manifestations of Granulomatosis with Polyangiitis. Cesk Slov Oftalmol. Spring 2019;74(5):167-174.

2. Lutalo PMK, D'Cruz DP. Diagnosis and classification of granulomatosis with polyangiitis (aka Wegener's granulomatosis). J 
Autoimmun 2014;48-49:94-8.

https://doi.org/10.1016/j.jaut.2014.01.028

3. Grygiel-Górniak B, Limphaibool N, Perkowska K, Puszczewicz M. Clinical manifestations of granulomatosis with polyangiitis: key considerations and major features. Postgrad Med 2018;130(7):581-596

https://doi.org/10.1080/00325481.2018.1503920

4. Greco A, Marinelli C, Fusconi M, Macri GF, Gallo A, De Virgilio A, Zambetti G, de Vincentiis M. Clinic manifestations in granulomatosis with polyangiitis. Int J Immunopathol Pharmacol. 2016;29(2):151-9.

https://doi.org/10.1177/0394632015617063

5. Tarabishy AB, Schulte M, Papaliodis GN, Hoffman GS. Wegener's granulomatosis: clinical manifestations, differential diagnosis, and management of ocular and systemic disease. Surv Ophthalmol 2010;55(5):429-44.

https://doi.org/10.1016/j.survophthal.2009.12.003

6. Hoffman GS, Kerr GS, Leavitt RY, et al. Wegener's granulomatosis: an analysis of 158 patients. Ann Intern Med 1992;116:488-98.

https://doi.org/10.7326/0003-4819-116-6-488

7. Villa-Forte A, Clark TM, Gomes M, et al. Substitution of methotrexate for cyclophosphamide in Wegener's granulomatosis. A 12-year single-practice experience. Medicine (Baltimore) 2007;86:269-77.

https://doi.org/10.1097/MD.0b013e3181568ec0

8. Gheita TA, Abd El Latif EM. Relationship of ocular presentation in granulomatosis with polyangiitis to autoantibodies and disease activity. Z Rheumatol 2019;78(3):281-286.

https://doi.org/10.1007/s00393-018-0495-5

9. Harper SL, Letko E, Samson CM, Zafirakis P, Sangwan V, Nguyen Q, Uy H, Baltatzis S, Foster CS. Wegener's granulomatosis: the relationship between ocular and systemic disease. J Rheumatol 2001;28(5):1025-32.

10. Leavitt RY, Fauci AS, Bloch DA, Michel BA, Hunder GG, Arend WP, Calabrese LH, Fries JF, Lie JT, Lightfoot RW Jr. The American College of Rheumatology 1990 criteria for the classification of Wegener's granulomatosis. Arthritis Rheum 1990;33(8):1101-7. https://doi.org/10.1002/art.1780330807

11. DeREMEE RA, McDonald TJ, Harrison EG Jr, Coles DT. Wegener's granulomatosis. Anatomic correlates, a proposed classification. Mayo Clin Proc 1976; 51(12):777-81.

12. Sfiniadaki E, Tsiara I, Theodossiadis P, Chatziralli I. Ocular Manifestations of Granulomatosis with Polyangiitis: A Review of the Literature. Ophthalmol Ther. 2019;8(2):227-234. https://doi.org/10.1007/s40123-019-0176-8

13. Ahmed M, Niffenegger JH, Jakobiec FA, et al. Diagnosis of limited ophthalmic Wegener granulomatosis: distinctive pathologic features with ANCA test confirmation. Int Ophthalmol 2008;28:35-46. https://doi.org/10.1007/s10792-007-9109-y

14. Davila-Camargo A, Tovilla-Canales JL, Olvera-Morales O, Rodríguez-Cabrera L, Ball-Burstein S, Nava-Castañeda Á. Orbital manifestations of granulomatosis with polyangiitis: 12-year experience in Mexico City. Orbit 2020;39(5):357-364. https://doi.org/10.1080/01676830.2020.1737717
15. Cleary JO, Sivarasan N, Burd C, Connor SEJ. Head and neck manifestations of granulomatosis with polyangiitis. Br J Radiol 2021;94(1119):20200914.

https://doi.org/10.1259/bjr.20200914

16. Mur T, Ghraib M, Khurana JS, Roehm PC. Granulomatosis with Polyangiitis Presenting with Bilateral Hearing Loss and Facial Paresis. OTO Open 2019;3(1):2473974X18818791. https://doi.org/10.1177/2473974X18818791

17. Allende DS, Booth CN: Wegener's granulomatosis of the breast: A rare entity with daily clinical relevance. Ann Diagn Pathol 2009; 13: 351-357 https://doi.org/10.1016/j.anndiagpath.2009.04.005

18. Kariv R, Sidi Y, Gur H. Systemic vasculitis presenting as a tumorlike lesion. Four case reports and an analysis of 79 reported cases. Medicine (Baltimore). 2000;79(6):349-59. https://doi.org/10.1097/00005792-200011000-00001

19. Schönermarck U, Lamprecht P, Csernok E, Gross WL. Prevalence and spectrum of rheumatic diseases associated with proteinase 3-antineutrophil cytoplasmic antibodies (ANCA) and myeloperoxidase-ANCA. Rheumatology 2001. https://doi.org/10.1093/rheumatology/40.2.178

20. Yates M, Watts RA, Bajema IM, Cid MC, Crestani B, Hauser T, Hellmich B, Holle JU, Laudien M, Little MA, Luqmani RA, Mahr A, Merkel PA, Mills J, Mooney J, Segelmark M, Tesar V, Westman K, Vaglio A, Yalçındağ N, Jayne DR, Mukhtyar C. EULAR/ERA-EDTA recommendations for the management of ANCA-associated vasculitis. Ann Rheum Dis 2016;75(9):1583-94

https://doi.org/10.1136/annrheumdis-2016-209133

\section{GRANULOMATOSIS WITH POLYANGIITIS (WEGENER'S GRANULOMATOSIS): CASE REPORT G. Bagužytė, D. Užkuraitytė, A. Sidaraitė, L. Bandzienè, D. Stanislovaitienè}

Keywords: Wegener's granulomatosis, granulomatosis with polyangiitis, vasculitis, ANCA, necrotizing granuloma, sinonasal disease, ocular manifestations of systemic disease.

Summary

Granulomatosis with polyangiitis, or Wegener's granulomatosis, is a rare autoimmune disease that usually affects the airways and kidneys. With ophthalmological changes, the disease begins in 30 - 50 percent. cases. The diagnosis is confirmed by specific histological changes - granulomatous inflammation detected by examination of the biopsy material from the artery or perivascular area of the affected organ and a positive result of antineutrophilic cytoplasmic antibodies. The outcome of granulomatosis with polyangiitis can be fatal, but timely diagnosis and modern possibilities of individualized treatment with cytotoxic and immunosuppressive drugs significantly improve the prognosis of the disease. This publication presents a clinical case of granulomatous polyangiitis in which the diagnosis is suspected in the presence of ophthalmological signs. After confirmation of the diagnosis, medical and surgical treatment was applied, remission of granulomatosis with polyangiitis was achieved.

Correspondence to: deimante.uzkuraityte@gmail.com

Gauta 2021-05-04 